
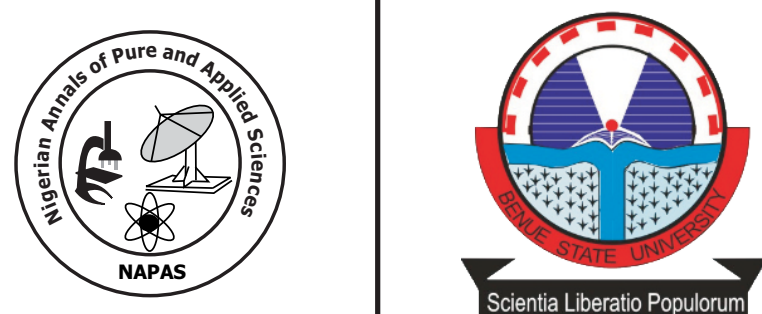

\title{
Growth Performance and Survival of Clarias gariepinus (Burchell, 1822) Fingerlings Fed Sweet Potato Leaf Meal (SPLM) as Partial Replacement for Soya Beam Meal (SBM)
}

\author{
${ }^{1}$ Ogaga, A., ${ }^{1}$ Ebiobowei, A. and ${ }^{2}$ Elijah, I. 0. \\ ${ }^{1}$ Department of Fisheries and Aquatic Studies \\ Niger Delta University, Wilberforce Island, Bayelsa, Nigeria. \\ 2Department of Biological Sciences, \\ Niger Delta University, Wilberforce Island, Bayelsa State, Nigeria.
}

\section{Abstract}

This study was designed to assess the suitability of using sweet potato leaf meal (SPLM) as a substitute for the complete or partial replacement of soya beans as protein source in fish feed formulation. One hundred and sixty Clarias gariepinus fingerlings were fed different levels of experimental diets containing $40 \%$ crude protein. Sweet potato leaf mealwas used at different levels of $10 \%$ (Diet/Treatment 2 i.e. T2), 20\% (T3) and $30 \%$ (T4), while $0 \%$ served as control (T1). Fingerlings were fed diet at $5 \%$ of their body weight for 42 days. This study determined the growth, survival and the best inclusion rate of SPLM in the diet which was conducted in a plastic tank. All experimental diet were accepted by the Clarias gariepinus fingerlings without impairing growth. The highest mean weight gain $(2.5 \pm 0.09 \mathrm{~g})$ was obtained in fish fed with $10 \%$ SPLM inclusion (T2), while the least $(1.8 \pm 0.09 \mathrm{~g})$ was recorded in T4 i.e. $30 \%$ inclusion. Similar trend was obtained for length increase, protein efficiency and percentage survival. All fish were good in condition except those offered diet T4. The best SPLM inclusion level of the study was obtained in T2.

Key words: Alternative feed, Potato leaf, meal inclusion rate, protein efficiency, growth performance, percentage survival. 


\section{Introduction}

The policies and programmes of successive Nigerian governments have over the years focused on agriculture, as a means of creating large scale employment and wealth sustainably. With the increasing human population (FAO, 2005) and large gap created in trying to meet the protein requirements, aquaculture, therefore, provides an alternative and effective means of meeting the short fall (FAO, 2013). Consequently, aquaculture is deemed to be growing across the globe by $10 \%$ annually (FAO 2012; FAO 2014) accounting for more than $30 \%$ of all fish consumed. Notwithstanding, fish production is still lagging behind compared to demand (Asuwaju et al., 2015). Principal factors militating against fish production include high cost of fish feed ingredients especially of protein origin (Nwanna, 2002; Ogbe et al., 2004; Nwanna et al., 2008) requiring about $60-70 \%$ of the aquaculture cost. The evaluation of alternative protein source especially those of plant origin has become necessary and urgent (Adeniyi, 2015).

The shortage of feed ingredients especially of protein origin has no doubt remained a major constraint to the much-needed advances in aquaculture in the face of dwindling resources from capture fisheries (Ogunji et al., 2005, FAD 2006, Sotolu and Faturoti 2009). Studies have shown that protein of vegetable sources, Ogunji et al., 2005 (pigeon pea), Reyes and Fermin, 2003 (pigeon pea), Modubuike, 2006 (Ipomoea asarifolia), Islam et al., 2012 (Sweet potato), Adewolu and Adamson, 2008 (Amaranthus spinosis) have high potential to supply the muchneeded protein needed for optimum animal productivity (Nwana et al., 2008). The antinutritional factors in potato leaves (invertase, protease inhibitor) which could impair fish growth must be reduced or completely eliminated by ensuring proper processing (Adewole 2008) through oven or sundrying, boiling or steaming and grinding prior to their inclusion in fish feed (Sotolu and Faturoti, 2009).

Sweet potato leaves are cooked as vegetable in many parts of the world. They are rich in vitamin B, B-carothene, iron, calcium, zinc and protein (Islam et al. 2003; Islam, 2006). The leaves are not consumed, but typically abandoned in the farm. Hence, the incorporation of potato leaves into fish feed could reduce the costs of feed formulation and results in the conversion of waste to wealth. Sweet potato leaf meal fed to Tilapia zilli and channel cat fish by Adewolu (2008) and Lochmann et al., (2010) respectively as dietary protein source for 10 weeks resulted in growth increase and no compromise on health and survival of fish. This study was therefore design to assess the growth performance and survival of Clarias gariepinus fed sweet potato leaf meal as partial replacement for soya bean in fish diet.

\section{Materials and methods Study Area}

The study was done at the fisheries and aquatic studies section of the teaching and research farm of the Niger Delta University, Wilberforce Island, Bayelsa State, Nigeria.

\section{Experimental System}

Sixteen rectangular plastic containers of 25 litres capacity were used as holding facility. The bowls were filled to ${ }^{2} / 3$ of the volume with water. The water was poured into the plastic bowls in a splash to aid proper aeration. Four different diets were prepared - 10\% (Diet/Treatment 2 i.e. T2), $20 \%$ (T3), 30\% (T4) inclusion rate of sweet potato leaf meal (SPLM) and $0 \%$ SPLM as the control (T1). The experiment was set up with the treatment in a completely randomized design. Four aquaria (plastic bowls) were used for each treatment. Ten Clarias gariepinus fingerlings were placed in each aquaria randomly sourcing and formulation.

\section{Experimental Feed Ingredients}

Fresh leaves of sweet potato (Ipomoea batata) were collected from Niger Delta University Teaching and Research Farm, Wilberforce Island, Bayelsa State, Nigeria. The samples collected were washed thoroughly with tap water to remove dirt and debris, drained and spread in a flat board for quick and homogenous solar drying for 2 weeks. Dried samples were ground to fine powder in readiness for incorporation in feed formulation alongside other milled ingredients (fish meal, soya bean meal, yellow maize, groundnut cake, table salts, vitamin and mineral premix and starch - the binder). Four experimental diets which have $40 \%$ crude protein were prepared using sweet potato leaf mineral at varying inclusion levels of $10 \%, 20 \%, 30 \%$ and $0 \%$ (control). The composition of each diet is shown in the (Table I). All ingredients are finely ground, sieved and weighed according to the recommended proportion in a clean bowl and mixed thoroughly. A measured quantity of water and starch prepared in a gelatinized form were added to the respective mixture. It was well stirred and made to pass through a meat mincer to produce strands of feed which are cut into bits (pellets). They were then sun dried until a constant weight was obtained and allowed to cool and packaged in readiness for fish feeding. 
Table I: Gross Composition of Experimental Diets Ingredients

\begin{tabular}{lllll}
\hline \multicolumn{1}{c}{ Ingredients } & \multicolumn{1}{c}{$\begin{array}{c}\text { Diet 1 } \\
\text { 0\% SPLM }\end{array}$} & \multicolumn{1}{c}{$\begin{array}{c}\text { Diet 2 } \\
\text { 10\% SPLM }\end{array}$} & \multicolumn{1}{c}{$\begin{array}{c}\text { Diet 3 } \\
\text { 20 SPLM }\end{array}$} & \multicolumn{1}{c}{ Diet 4 } \\
& 0.0 & 1.5 & 3.0 & 4.5 \\
Sweet potato leaf meal & 15.0 & 13.5 & 12.0 & 10.5 \\
Soya bean meal & 26.0 & 26.0 & 26.0 & 26.0 \\
Fish meal & 48.0 & 48.0 & 48.0 & 48.0 \\
Yellow maize meal & 6.0 & 6.0 & 6.0 & 6.0 \\
Groundnut cake meal & 3.5 & 3.5 & 3.5 & 3.5 \\
Vitamin/mineral premix & 0.5 & 0.5 & 0.5 & 0.5 \\
Salt & 1.0 & 1.0 & 1.0 & 1.0 \\
Starch & $\mathbf{1 0 0}$ & $\mathbf{1 0 0}$ & $\mathbf{1 0 0}$ & $\mathbf{1 0 0}$ \\
\hline Total & & & & \\
\hline
\end{tabular}

The experimental animal (Clarias gariepinus fingerlings) numbering about 200 were obtained from a reputable fish farm, their average weight was $2.4 \mathrm{~g}$ while the average length at time of stocking was $4.4 \mathrm{~cm}$. The fishes were allowed to acclimatize one week (period in which they were denied food). The fingerlings were fed at $5 \%$ body weight per day. Dissolved oxygen, $\mathrm{pH}$ and temperature of the water were monitored daily using Hach's digital $\mathrm{DO}$ and $\mathrm{pH}$ meter and laboratory thermometer.

\section{Growth Analysis}

Relative growth rate and specific growth rates were determined by methods described by Olivia et al, 2001 and Sveterr et al., 2000 while condition factor, feed conversion ratio, protein efficiency ratio and percentage weight gain were computed by methods of Bagenal and Tesch (1978), Utne (1979).

\section{Statistical Analysis}

Data generated were used to calculate the growth, survival and nutrient utilization parameter for different treatments. The data were subjected to Analysis of Variance (ANOVA). The Duncan multiple range test was used in separating the means of individual treatment at 0.05 level of significance (Duncan, 1990).

\section{Result}

The mean weight gain of fingerlings increased from initial values in all the dietary treatments. Highest mean weight gain $(2.5 \pm 0.09 \mathrm{~g})$ was obtained in Clarias gariepinus fingerlings fed on dietary treatment 2 (at 10\% SPLM inclusion to replace soya bean meal), while treatment $4(30 \%$ inclusion level) had the lowest $(1.8 \pm 0.09 \mathrm{~g})$. There was no significant difference $(\mathrm{P}>0.05)$ in the weight gain in fingerlings fed treatment 1,2 and 3 but there was significant difference $(\mathrm{P}<0.05)$ between those fed with these three treatments and treatment 4.

Similarly, fingerlings fed treatment 2 (at $10 \%$ SPLM) recorded the highest length increase $3.3 \pm 0.10 \mathrm{~cm}$ with a corresponding least length increase reported in those fed with treatment 4 (30\% SPLM inclusion level). Fingerlings fed treatment 2 were significantly different from those of treatments (T) 1,3 and 4. The protein efficiency ratio (PER) and percentage survival followed similar pattern in which the highest were recorded in fish fed T2 and the least in those fed T4. The feed conversion ratio was highest in fish fed $\mathrm{T} 4(2.67)$ and lowest in T2(1.92 $\pm 0.19 \%)$. Percentage survival was in the order $\mathrm{T} 2>\mathrm{T} 1>\mathrm{T} 3>\mathrm{T} 4$ while all fish were good in condition except those of $\mathrm{T} 4$.

Table 2: Showing Mean growth and nutrient utilization parameters of Clarias gariepinus fed on experimental diets.

\begin{tabular}{lllll}
\hline PARAMETER S & DIET 1 (0\%) & DIET 2 (10\%) & DIET 3 (20\%) & DIET 4 (30\%) \\
\hline Mean initial weight (g) & $2.4 \pm 0.20^{\mathrm{a}}$ & $2.4 \pm 0.20^{\mathrm{a}}$ & $2.4 \pm 0.20^{\mathrm{a}}$ & $2.4 \pm 0.20^{\mathrm{a}}$ \\
Mean final weight (g) & $4.7 \pm 0.45^{\mathrm{a}}$ & $4.9 \pm 0.43^{\mathrm{a}}$ & $4.5 \pm 0.47^{\mathrm{a}}$ & $4.2 \pm 0.32^{\mathrm{b}}$ \\
Mean weight gain (g) & $2.3 \pm 0.09^{\mathrm{a}}$ & $2.5 \pm 0.09^{\mathrm{a}}$ & $2.1 \pm 0.09^{\mathrm{a}}$ & $1.8 \pm 0.09^{\mathrm{b}}$ \\
Mean total body length (cm) & $7.2^{\mathrm{a}}$ & $7.7^{\mathrm{b}}$ & $7.19^{\mathrm{a}}$ & $6.9^{\mathrm{a}}$ \\
Mean length increase (cm) & $2.8 \pm 0.10^{\mathrm{a}}$ & $3.3 \pm 0.10^{\mathrm{b}}$ & $2.8 \pm 0.10^{\mathrm{a}}$ & $2.6 \pm 10^{\mathrm{a}}$ \\
Food conversion ratio (FCR) & $2.09 \pm 0.19^{\mathrm{a}}$ & $1.92 \pm 0.19^{\mathrm{b}}$ & $2.29 \pm 0.19^{\mathrm{a}}$ & $2.67 \pm 0.19^{\mathrm{a}}$ \\
Protein efficiency ratio (PER) & $1.14 \pm 0.14^{\mathrm{a}}$ & $1.24 \pm 0.14^{\mathrm{a}}$ & $1.04 \pm 0.14^{\mathrm{b}}$ & $0.89 \pm 0.14^{\mathrm{bc}}$ \\
Condition factor (CF) & $1.26 \pm 0.17^{\mathrm{a}}$ & $1.07 \pm 0.17^{\mathrm{b}}$ & $1.26 \pm 0.17^{\mathrm{a}}$ & $1.28 \pm 0.17^{\mathrm{a}}$ \\
Percentage survival (\%) & 90 & 95 & 85 & 75 \\
\hline
\end{tabular}

Means were computed from triplicate values. Along the column, means with the same alphabets are not significantly different according to the Duncan Statistics 


\section{Discussion}

In this study, all the experimental diets were accepted by the fish. This is indicative of the fact that there was proper processing and the level of SPLM incorporation did not in any way affect the palatability of the diet (Francis et al., 2001; Sotolu and Faturoti, 2009). The processing technique used in the study (drying and grinding) may have drastically minimized anti-nutritional factors in the SPLM (Adewolu, 2008). The best feed conversion ratio was recorded in fish fed diet 2 $(10 \%$ SPLM) although in close range with those fed diet 1,3 and 4. This implies that the SPLM did not compromise growth even up to $30 \%$ soya beans replacement level, this compares favourably with studies of Adewole (2008), Tamir et al., (2009); Lochmann et al., 2012 reported that SPLM was an effective energy source up to $230 \mathrm{gkg}^{-1}$ diet and supported growth in channel catfish while study of Tamir et al., (2009) revealed that $100 \mathrm{gkg}^{-1}$ dietary meal inclusion of SPLM supported growth of Ross broiler chicks. These various researchers have proven that SPLM inclusion less than $50 \%$ in animal diet are able to support growth. Their submissions therefore corroboratesthe findings of this study in which the SPLM inclusion ranged between 10-30\%.

In conclusion, this study showed that the inclusion level of SPLM in the diet of Clarias gariepinus fingerlings used as partial replacement forsoya beanmeal (SBM), has a positive nutrient utilization that resulted in fish growth and survival. The SPLM inclusion/replacement for $\mathrm{SBM}$ at $10 \%$ level is more suitable for fish production. All parameters determined in this research namely mean (Weight gain, length increase, feed conversion ratio, protein efficiency, condition factor and percentage survival) had their optimum values obtained at $10 \%$ (T2) SPLM replacement level for SBM.

\section{References}

Adewolu, M.A and A.A. Adamson (2008). Amaranthus spinosis Leaf Meal as potential dietary protein source in the practical diets for Clarias gariepinus (Burcheli, 1822) fingerlings. International Journal of Zoological Research7 (2): 128-137

APHA (2005). Standard methods for the Examination of water and waste water $21^{\text {st }}$ edn.american Public Health Association, Washington, DC.

Asuwaju, F.P; A.N, Olarenwaju; O.K, Kareem; O. Orisasona; R.A. Obande and G.O. Omorodion (2015). Evaluation of Growth Performance and Carcas Composition of Clarias gariepinus Fingerlings Fed varying crude protein diets. Proceedings of $30^{\text {th }}$ Fisheries Society of Nigeria (FISON) Annual Conference, Nov. $22^{\text {nd }}-27^{\text {th }} 2015$. Pp. 184- 187.

Bagenal, T.B. and E.W. Tesch (1978). Age and Growth In: T.B. Agenal (Ed.). method for Assessment of Fish Production in Fresh Water. $3^{\text {rd }}$ Ed. Blackwell Scientific Publication, Osney Mead, Oxford Pp. 101 136.

Duncan, D.B. (1990). Multiple Range and Multiple F. Test, Biometrics. 11:1-42.

Food and Agricultural Organization (FAO) 2006. The state of world Fisheries and Aquaculture, Rome. FAO Fisheries Technical Paper 500, $145 \mathrm{Pp}$.

Food and Agricultural Organization (FAO) 2005.Fishstat plus. Universal Software for Fishery Statistical Time Series. Vers. 2.30. FAO Fisheries Department, Fishery Information; Data and Statistics Unit. www.fao.org/fishery/statistic/software/fis hstat/en.

Food and Agricultural Organization (FAO) 2012. The State of the World Fisheries. Food and Agriculture Organization. Rome. Italy. $230 \mathrm{p}$.

Food and Agricultural Organization (FAO) 2013. Food and Agricultural Organization of the United Nations. Report of the Fourth Meeting of the Regional Fishery Body Secretariats Network (RSN - 4), Rome, 13 July 2012. FAO Fisheries and Aquaculture Report No. 1013.28p.

Food and Agricultural Organization (FAO) 2014. State of the World Fisheries and Aquaculture, Rome. 223p.

Francis G.H., P.S. Makkar and K. Beckar (2001). Anti-nutritional factors Present in plant derived alternative fish feed ingredients and their effects in fish. Aquaculture 199 (3-4): $197-228$.

Hasting W.H. (1976). Nutritional Requirements and Field Technology in Advances in Aquaculture paper Presented at the FAO Technical Conference on Aquaculture, Tyoto Japan. $75 \mathrm{Pp}$.

Islam, S; Y. Yoshimoto and O. Yamakawa (2003). Distribution and physiological function of Catteoylquinic Acid Deriavatives in Sweet Potato Genotypes. Journal ofFood Science 68: 111-116.

Islam, S (2006). Sweet Potato leaf: its Potential effect on human health and nutrition. Jn. Food Sci. 71:R13 - R21. Use of cassava in Livestock and aquaculture feeding programmes. 
Lochmann R.T. (2012). Jn. SCi. Food Agric 93 (6): 1365 - 9. Doi:10.1002 (Jsta.5898.E Pub. 2012 Oct.

Madubuike F.N. (2006). Assessment of Ipomoea asarifolia leaf Meal as feed ingredient in Broiler chich Production. Pakistan Journal of nutrition 5:46-50.

Nwanna, L.C. (2002). Performance of Hybid Clariid Fingerlings male Heterobranchus bidorsalis Female Clarias gariepinus fed poultry layer waste diets in glass tanks. Journal of Applied Aquaculture 12(3): 99106.

Nwanna, L.C. A.E. Falaye and A.O. Sotolu (2008). Water hyacinth (Eichhornia crassifies (Mart Solms): A sustainable Protein Sources for fish feed in Nigeria. Food Health and Environmental issues in Developing countries. The Nigeria situation Adeboye O.C. Taiwo K. A. and Fatufe A. A. (Eds). Alexander Von Humboldt Foundation, Bonn Germany. P 187-194.

Ogbe F.G; Tiamiyu, L.O. and Eze P.N. (2004). Growth Performance of Clarias gariepinus fingerlings fed earthworm meal Lumbricus terrestis as replacement for fish meal: In Proceedings of the Fisheries Society of
Nigeria Conference (FISON) 2004. Pp. 214 -218 .

Ogunji J.O, Uwadiegwu; D Osuigwe and M. Wirth (2005). Effects of different processing methods of pigeon Pea (Cajanus caja) on the hematology of African cat-fish (Clarias gariepinus). Conference on international Agricultural Research for Development. Deuscher Tropentage, 2005 Stuttgart Hohenheim $11-13$.

Sotolu, A.O. and E.O. Faturoti (2009). Digestibility and nutritional values of differently processed Leucaena Leucocephala (Lam de wit) seed meals in diets of African cat fish (Clarias gariepinus). Middle East Journal of Scientific Research 3: 190-199.

Svetterr (2000). Applied statistics for Scientific studies. Africa link Press 386P.

Tamir, B. W. Tsega (2009). Tropical Animal Health and Production 42 (4): 687-95

Utne, F. (1979). Standard Method and Terminology on Fin. Fish Nutrition. In: J. E. Halver and K. Trews (Eds) Fish Nutrition and Finfish Technologies H. Heinemasn and C. Borkin. Vol. 11:437-444. 